\title{
Magnetostratigraphy and biostratigraphy of the Carnian/Norian boundary interval from the Pizzo Mondello section (Sicani Mountains, Sicily)
}

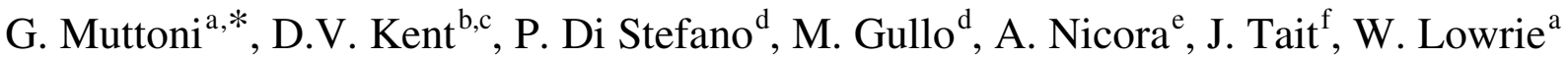 \\ ${ }^{a}$ Institute of Geophysics, ETH-Hönggerberg, CH-8053 Zürich, Switzerland \\ ${ }^{\mathrm{b}}$ Lamont-Doherty Earth Observatory, Palisades, NY 10964, USA \\ ${ }^{\mathrm{c}}$ Department of Geological Sciences, Rutgers University, Piscataway, NJ 08854, USA \\ ${ }^{\mathrm{d}}$ Dipartimento di Geologia e Geodesia, Università di Palermo, Italy \\ ${ }^{\mathrm{e}}$ Dipartimento di Scienze della Terra, Università di Milano, Italy \\ ${ }^{\mathrm{f}}$ Ludwig-Maximillians-Universität München, Germany
}

Received 3 December 1999; accepted for publication 8 September 2000

\begin{abstract}
The 146.5 m-thick Upper Triassic limestone section at Pizzo Mondello in the Sicani Mountains of western Sicily is characterized by high quality of exposure, accessibility, and stratigraphic continuity. Magnetostratigraphic results delineate 12 normal and reverse polarity magnetozones, labelled successively from the base upwards as PM1n, PM1r, PM6n, PM6r. The Carnian/Norian boundary, based on conodont biostratigraphy, falls somewhere in the PM3n to PM5n interval which corresponds to the E14n to E16n magnetozone interval in the Newark reference sequence of polarity reversals. Comparison of magnetobiostratigraphic data from the Newark basin, Pizzo Mondello and other Late Triassic marine sections available from the literature suggests the existence of a reduction in sedimentation rate in the Tethyan marine domain at around the Carnian/ Norian boundary. Although the Newark and the expanded Pizzo Mondello sections correlate well with each other, correlation with the condensed Kavur Tepe and Scheiblkogel sections is unsatisfactory. A re-interpretation of the Kavur Tepe results suggests that the section is younger than its previous correlation with the Newark section, and that it was deposited in the northern instead of the southern hemisphere. Most of the condensed Tethyan marine sections are seen to be highly discontinuous, as evidenced by concantenated conodont total range zones. (C) 2001 Elsevier Science B.V. All rights reserved.
\end{abstract}

\section{Introduction}

Late Triassic magnetostratigraphy and biostratigraphy has recently been investigated in both continental and Tethyan marine sequences. In the Tethys realm, magnetostratigraphic studies have been mainly conducted in condensed marine limestone sequences

\footnotetext{
* Corresponding author. Fax: +41-633-1065.

E-mail address: giom@mag.ig.erdw.ethz.ch (G. Muttoni).
}

which provided fossils usually claimed to be agediagnostic at the sub-stage level (e.g. Gallet et al., 1992, 1994). Unfortunately, these limestone facies are often affected by greatly reduced and/or irregularly varying rates of sedimentation which can distort the magnetic polarity sequence for correlation. In an attempt to circumvent this problem in the vicinity of the Carnian/Norian boundary, we have established the magnetostratigraphy of an expanded $146.5 \mathrm{~m}$-thick fossiliferous limestone section at Pizzo Mondello 


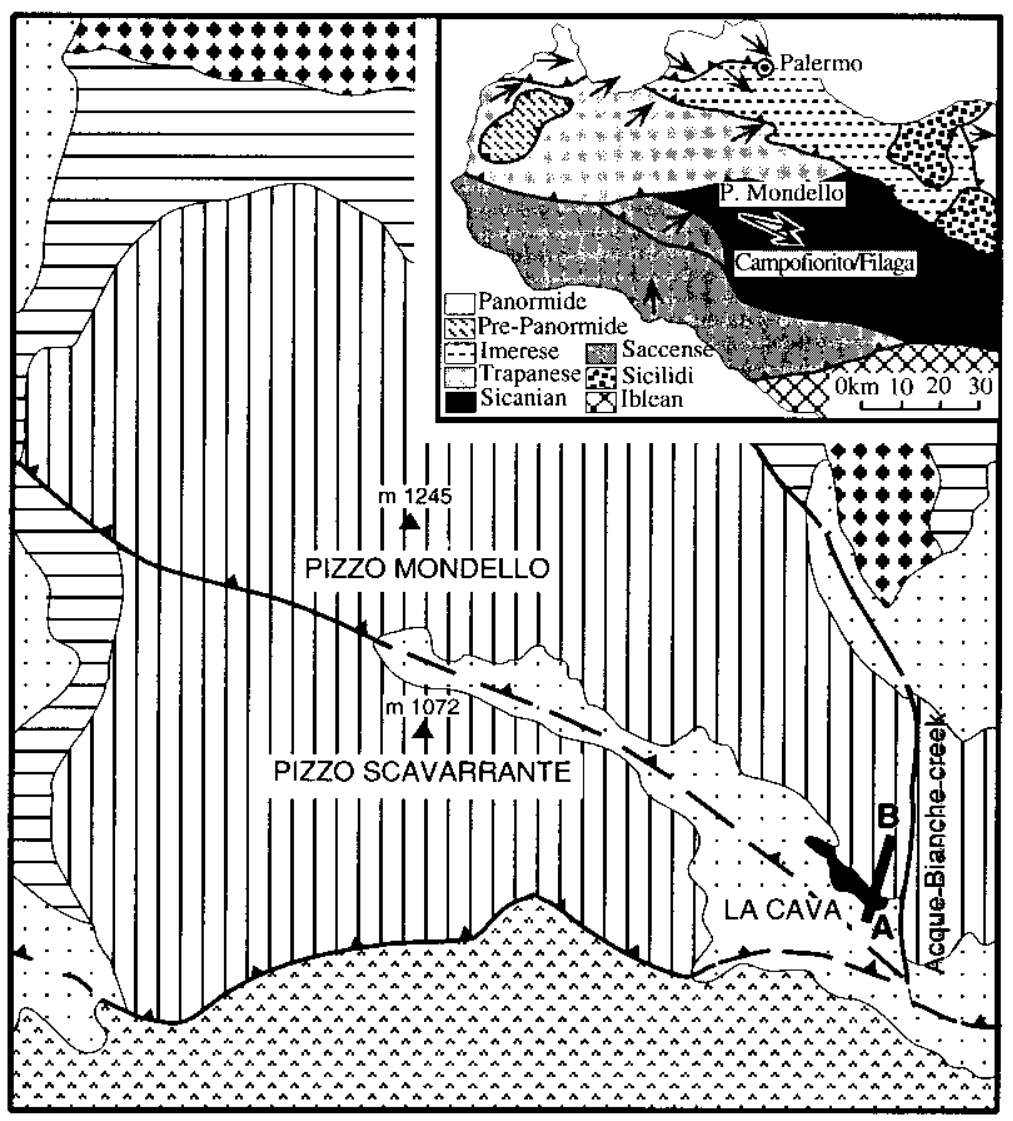



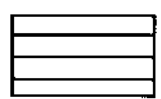

Pelagic limestones, marls, radiolarites and volcanics

Jurassic - Oligocene

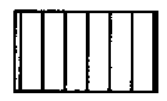

Cherty limestones

upper Carnian-Ahaetian

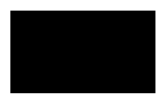

Marls and calcilutites

Middle - Upper Carnian
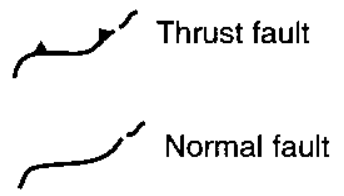

$A \sim B$ Studied section

Fig. 1. Geological map of the Pizzo Mondello area in the Sicani Mountains of western Sicily. Inset shows geologic map of central-western Sicily with paleomagnetic directions from Channell et al. (1990). See text for discussion.

located in the Sicani Mountains of western Sicily (Fig. 1). The aim of this study is to contribute to the development of an integrated geologic time scale for the Late Triassic that relates marine and nonmarine facies using the global record of geomagnetic polarity reversals. Accordingly, we attempt to correlate the magnetostratigraphic and biostratigraphic data from Pizzo Mondello with the reference sequence of polarity reversals from the Newark basin (Kent et al., 1995; Kent and Olsen, 1999) as well as with published data from other Late Triassic Tethyan limestone sections.

\section{Geological setting}

The Sicani Mountains are comprised of mainly pelagic sediments of Permian to Cenozoic age. They were deposited in a south Tethyan basinal area which was already defined in the Permian along the northern margin of Gondwana (Sicanian basin sensu Di Stefano, 1990). During Late Triassic times the Sicanian basin was flanked southwards by a carbonate shelf named the Siculo-Tunisian Platform (Di Stefano et al., 1996), which was in turn laterally transitional to the Tunisian evaporites.

The Sicani Mountains are a segment of the Sicilian thrust-and-fold belt which is characterized, like other regions of western Sicily, by polydeformational tectonics related to the Neogene Apenninic-Maghrebian orogeny (Oldow et al., 1990). The Pizzo Mondello thrust sheet is a dome structure resulting from the superposition of SSW-NNE and N-S striking folds, and consists of about $1200 \mathrm{~m}$ of pelagic carbonates, radiolarites and marls of Mesozoic to 
a) b) c) d)

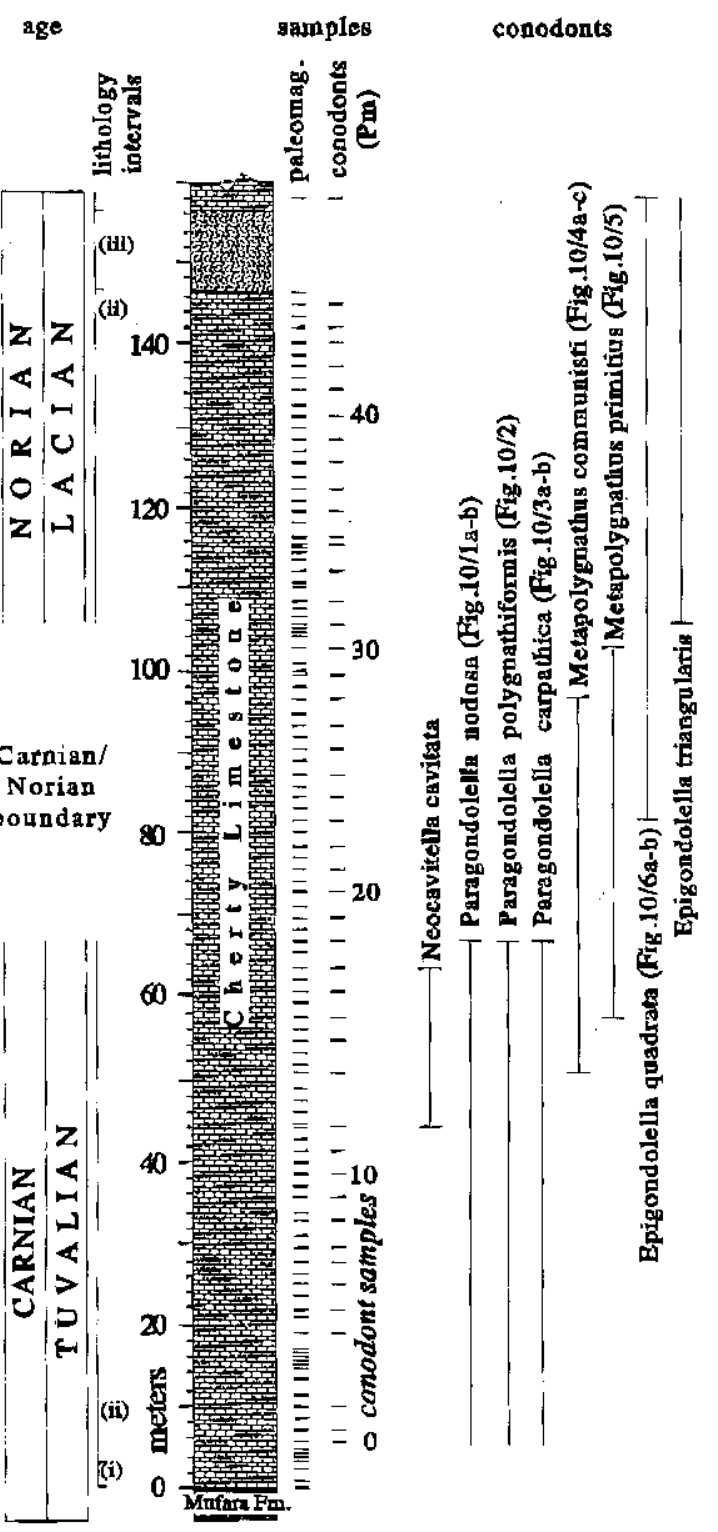

e)

VGP latitude rotated

(') f)

Polarity
$-90 \quad-45 \quad 0 \quad 45 \quad 90$

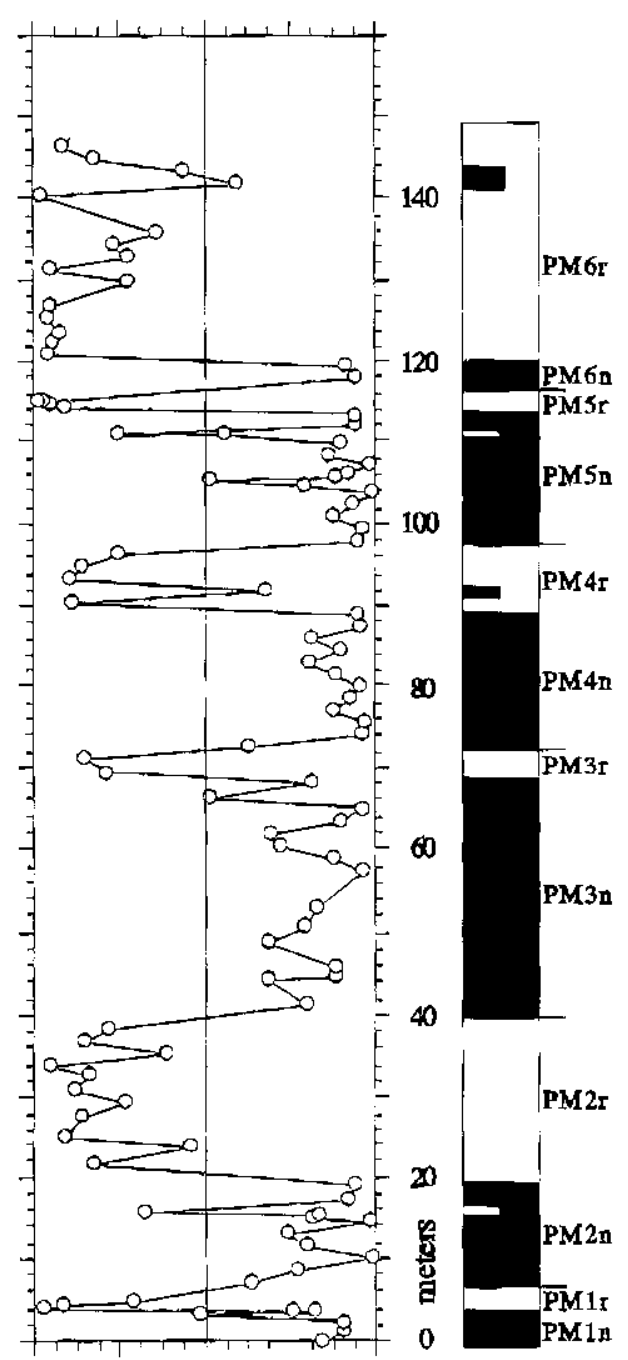

Fig. 2. The Carnian/Norian boundary Pizzo Mondello section, showing (a) the age determination of the section, (b) the lithology intervals described in the text, (c) the stratigraphic distribution of age-diagnostic conodonts (with, in parenthesis at the side of conodont names, a key reference to Fig. 10), (d) the stratigraphic position of the paleomagnetism and conodont samples, (e) the relative VGP latitudes of the characteristic component as a function of stratigraphic position and (f) the polarity interpretation. Magnetic polarity zones are shown by filled (open) bars for normal (reversed) polarity; single-sample polarity zones are shown by half bars. 
Cenozoic age. This unit overthrusts to the south a thick allochthonous complex of Neogene clays and evaporites attributed to the Gela Nappe (Bellanca et al., 1993; Bellanca, 1995, and references therein).

The Pizzo Mondello unit starts with a few meters of dark to gray marls and marly limestones of possible Julian to early Tuvalian (late Early to early Late Carnian) age pertaining to the Mufara Formation. These are overlain by over four hundred meters of evenly-bedded to nodular Halobia-bearing cherty calcilutites, hereafter referred to as Cherty Limestone, which yield conodonts of middle Tuvalian to late Sevatian (Middle Carnian to Late Norian) age (Gullo, 1996, and references therein and this study). The Cherty Limestone is conformably overlain by $20 \mathrm{~m}$ of Early- to Middle Rhaetian conodont-bearing calcilutites intercalated with gray-greenish marls (Portella Gebbia Limestone, Gullo, 1996), which are at some localities unconformably overlain by Liassic calcarenites and marls.

We focused our attention on the basal $146.5 \mathrm{~m}$ of the Cherty Limestone succession, of middle Tuvalian to Lacian age, at a section located near the village of Bivona, about $4 \mathrm{~km} \mathrm{SE}$ of the famous Permian megablocks of the Sosio Valley. The section was sampled at the locality 'La Cava' (I.G.M. topographic map, sheet 266 I NE 'Bivona', coordinates UB593661) along the south-eastern slope of an abandoned quarry at $700 \mathrm{~m}$ (Fig. 1).

\section{Lithostratigraphy}

The Upper Triassic Cherty Limestone at Pizzo Mondello can be subdivided into four main lithostratigraphic intervals, from base to top:

1. A basal 3 m-thick interval located just above the contact with the Mufara Fm., which is characterized by calcilutites with no or rare chert nodules.

2. A lower $143.5 \mathrm{~m}$-thick interval characterized by whitish-yellow well-bedded calcilutites, about $25 \mathrm{~cm}$-thick, with black chert nodules and levels, intercalated with a few $\mathrm{cm}$-thick black and yellowish marls. The calcilutites are wackestones and packstones with abundant pelagic bivalves (Halobids) concentrated mainly in the lower portion of the beds, associated with foraminifers, radiolar- ians, sponge spicules, sparce ammonoids and ostracods (Gullo, 1993; 1996). Calcispheres and calcareous nannofossils are also present and sometimes they constitute up to $80 \%$ of the rock volume (Bellanca et al., 1993; 1995). The thin-shelled bivalve concentrations commonly display a shelter porosity.

3. An intermediate $11.5 \mathrm{~m}$-thick interval of slumped and brecciated limestones (pebbly mudstones) showing the same lithology as interval (2).

4. An upper $267.5 \mathrm{~m}$-thick interval characterized by greyish to whitish calcilutites with chert nodules and levels, which forms a transition into grey-pinkish pseudonodular to nodular chert-bearing calcilutites. Dark, green or yellow chert nodules and levels are very abundant throughout the whole interval. The calcilutites are mudstone and wackestone with the same fossil content of interval (2). Halobian packstones in this interval are very rare.

We report the magnetostratigraphy of samples from interval (1) and interval (2) up to the boundary with interval (3) (Fig. 2b).

\section{Biostratigraphy}

The biostratigraphy of the Pizzo Mondello section relies on conodonts. Radiolarians and ammonoids, usually regarded as important biostratigraphic tools in Tethyan limestones, are poorly preserved at Pizzo Mondello. We performed further conodont sampling following an earlier study by Gullo (1996) to improve the biostratigraphic resolution across the Carnian/ Norian boundary. Samples for conodont biostratigraphy were collected with an average sampling interval of $3 \mathrm{~m}$. A total of 46 samples of about 4 kilograms each was obtained for dissolution in acetic acid using standard methods (Fig. 2c). Platform conodonts were found at Pizzo Mondello in association with ramiform conodonts Neohindeodella (dominant), Prioniodina, Chirodella, Grodella and Cornudina spp. The following stratigraphically important platform conodont events have been recognized at Pizzo Mondello, from base to top (Fig. 2d):

1. The Neocavitella cavitataSudar and Budurov range, from its first occurrence (FO) at meter 


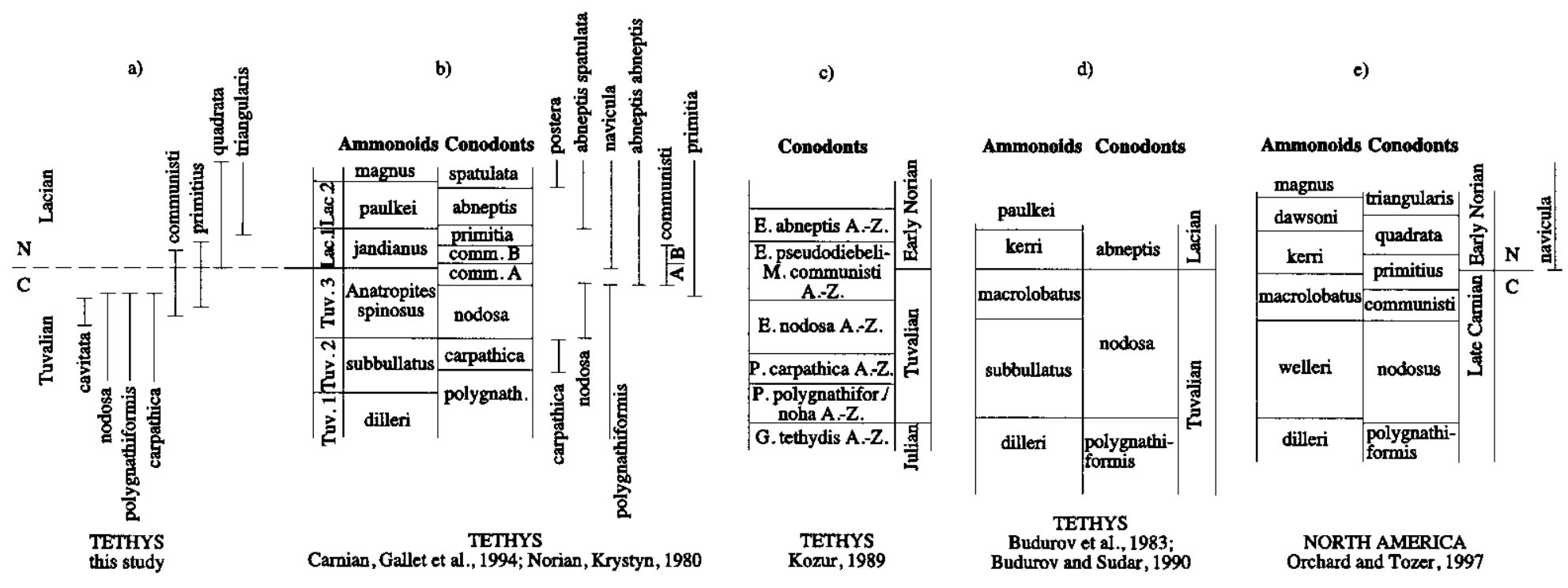

Fig. 3. (a) Tethyan conodont biostratigraphy from Pizzo Mondello compared with conodont and ammonoid scales from the Tethys of (b) Gallet et al. (1994); Krystyn (1980), (c) Kozur (1989), (d) Budurov et al. (Budurov and Sudar, 1990; Budurov and Sudar (1990); (e) is the North America conodont and ammonoid scale of Orchard and Tozer (1997). In panel (b) Tuv. is Tuvalian and Lac. is Lacian. 
level 44.25 (sample Pm 12) to its last occurrence (LO) at meter level 63.5 (sample Pm 17).

2. The coexistence of P. nodosa (Hayashi) (Fig. 10/1a and b), Paragondolella polygnathiformis (Fig. 10/2) (Budurov and Stefanov) and P. carpathica ${ }^{1}$ (Mock) (Fig. 10/3a-b) in the interval between meter level 5.5 (sample Pm 0) and meter level 66.5 (sample Pm 18).

3. The Metapolygnathus communisti (Hayashi) (Fig. 10/4a to c) range, from its FO at meter level 50.5 (sample Pm 13) to its LO at meter level 96.5 (sample Pm 28).

4. The Metapolygnathus primitius(Mosher) (Fig. 10/ 5) range, from meter level 57.5 (sample Pm 15) to meter level 102.5 (sample Pm 30).

5. The FO of Epigondolella quadrata Orchard $(=E$. abneptis subspecies A Orchard; Orchard, 1991b) (Fig. 10/6a and b) at meter level 81.5 (sample Pm 23); this species continues up to sample Pm 46 at the top of the section in all its onthogenic stages.

6. The FO of E. triangularis (Budurov) ( = E. abneptis subspecies B Orchard; Orchard, 1991a) at meter level 105.5 (sample Pm 31); this species continues above the top of the section.

\subsection{Interpretation of the biostratigraphic data}

Triassic stage boundaries are historically based on ammonoid biostratigraphy. The base of the Norian is usually placed at the base of the Jandianus and Kerri ammonoid zones in the Tethys and North America, respectively. Conodonts have been successively tied into the ammonoid zonation after fundamental studies performed in the Tethys realm (e.g. Krystyn, 1980; Vrielynck, 1987; Kozur, 1989; Budurov and Sudar, 1990) and North America (Orchard, 1983; 1991a,b; Orchard and Tozer, 1997. We compare conodont biostratigraphy from Pizzo Mondello (Fig. 3a) with conodont scales from the literature from the Tethys and North America (Fig. 3b-e). In the Tethys, the issue of conodont biostratigraphy and biochronology

\footnotetext{
${ }^{1}$ Considering their morphological characters and the stratigraphic distribution, Paragondolella carpathica and $P$. nodosa belong, in our opinion, to the same taxon, even though they differ in the number of denticles. Nevertheless, we maintain here the term Paragondolella carpathica to differentiate specimens of $P$. nodosa showing not more than three denticles along the platform margins.
}

around the Carnian/Norian boundary is not yet completely settled (see discussion below), whereas in North America data from western Canada seem to indicate that the Carnian/Norian boundary corresponds to the base of the Norigondolella navicula Zone which correlates with the base of the Kerri ammonoid zone (Orchard and Tozer, 1997) (Fig. 3e).

The conodont events (1) to (6) at Pizzo Mondello (Fig. 3a) are interpreted according to conodont biochronology from the literature (Fig. 3b-e).

1. The Neocavitella cavitata range is considered restricted to the upper part of the Carnian according to Sudar and Budurov (1979); Budurov and Sudar (1990).

2. The association Paragondolella nodosa, P. polygnathiformis and $P$. carpathicaand $P$.is regarded as middle-late Tuvalian (Tuvalian 2-3) in age (Vrielynck, 1987; Kozur, 1989; Budurov and Sudar, 1990). Krystyn (in Gallet et al., 1994) excludes that $P$. nodosa and $P$. carpathica could co-exist, and places the FO of $P$. nodosa to coincide with the LO of $P$. carpathica at the base of the late Tuvalian (Tuvalian 3) (Fig. 3b). However, both conodonts are found together at Pizzo Mondello, questioning the validity of Krystyn's event "carpathica LO-nodosa FO" as a proxy for the location of the base of the late Tuvalian. In any case, the LO of $P$. nodosa, $P$. polygnathiformisand $P$. carpathicapredates in general the end of the Carnian (Krystyn, 1980; Vrielynck, 1987; Kozur, 1989; Budurov and Sudar, 1990; Gallet et al., 1994).

3. The Metapolygnathus communisti range. Krystyn (1980) differentiates two subspecies of $M$. communisti, namely a morphotype A, which first occurs slightly below the Carnian/Norian boundary, and a morphotype $\mathrm{B}$, which first occurs just above the boundary (Fig. 3b). M. communisti $\mathrm{B}$ is a rare subspecies recognized only at Feuerkogel, Austria, by Krystyn (pers. comm. to AN); it is however considered by Orchard (pers. comm. to AN) a doubtful subspecies which appears to be morphologically rather close to $P$. nodosa. The typical $M$. communisti seems to correspond to morphotype A (Orchard, pers. comm. to AN). According to Kozur (1989); Budurov and Sudar (1990), in the Tethyan-Pacific conodont province 



Fig. 4. Thermal decay of orthogonal-axes isothermal remanent magnetization (IRM) for representative Pizzo Mondello samples bearing dominant magnetite. A minor amount of another ferromagnetic mineral, possibly a sulfide phase, or the presence of a coarser grain-size fraction is suggested by the change in slope of the curves between $200^{\circ} \mathrm{C}$ and $400^{\circ} \mathrm{C}$; there is no indication of hematite. Symbols are as follows: open circles $0.2 \mathrm{~T}$, solid circles $0.6 \mathrm{~T}$, open squares $2.5 \mathrm{~T}$.

the undifferentiated $M$. communisti (i.e. close to M. communisti A of Krystyn, 1980) occurs from the base of the late Tuvalian (Tuvalian 3) up to the Early Norian, whereas Orchard and Tozer (1997) reported the presence of M. communisti in the Late Carnian of western Canada and pointed out its progressive disappearence towards the Carnian/Norian Boundary. These observations are in general contrast with the much shorter distribution of $M$. communisti A reported by Krystyn (1980) in his standard ammonoid and conodont zonation (Fig. 3b). At Pizzo Mondello, the communisti populations are characterized by specimens of Late Carnian/Early
Norianz undifferentiated $M$. communisti (i.e. close to M. communisti A of Krystyn, 1980), whereas morphotype B was not observed.

4. The Metapolygnathus primitiusrange straddles the Carnian/Norian boundary according to Orchard and Tozer (1997).

5. The FO of Epigondolella quadrata $(=$ E. abneptis subspecies A; Orchard, 1991b) occurs in the latest Tuvalian (latest Carnian) in the Tethys (Vrielynck, 1987) (Fig. 3b), or in the earliest Norian at the boundary between the Upper Metapolygnathus primitius Zone and the 'Abneptis' A Zone in North America (Orchard, 1991 a,b) (Fig. 3e). 
a) ma -1.15



c) $\operatorname{mna} 79.0 \mathrm{a}$

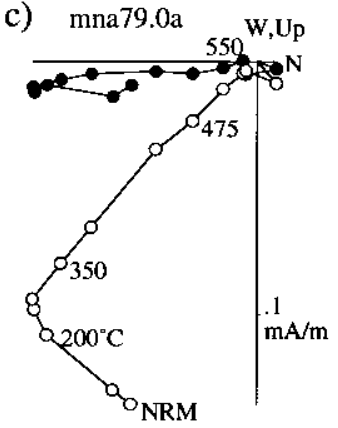

e) $\operatorname{mna92.5a}$

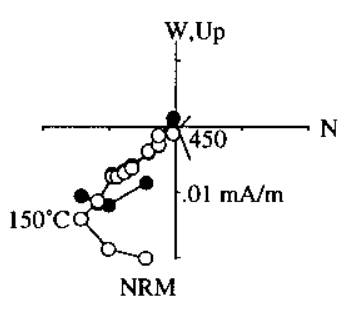

mna4.5a

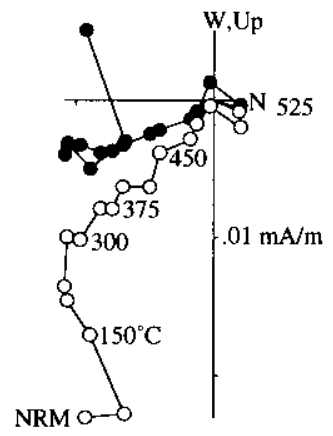

mna88.0a

d)

b)
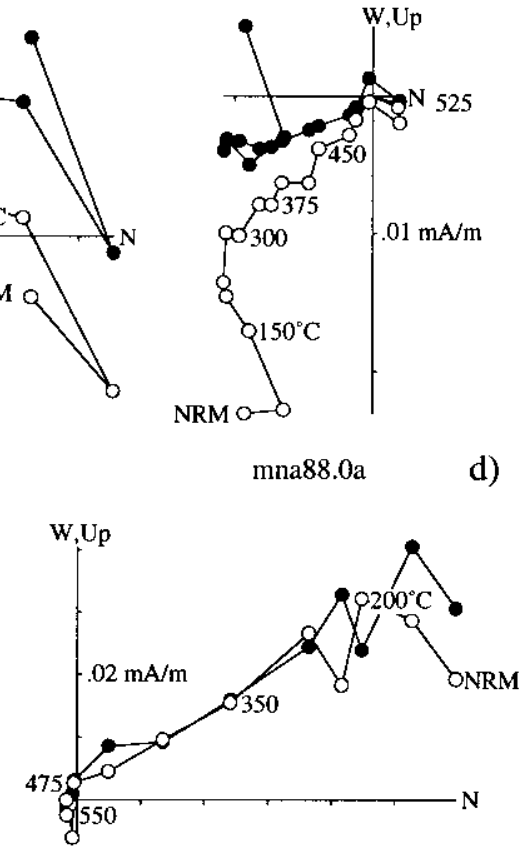

In Situ Coordinates

Fig. 5. Zijderveld thermal demagnetograms of the natural remanent magnetization (NRM) of representative samples from Pizzo Mondello with reversed ( $a, d, f)$ and normal (b, c, e) polarity characteristic magnetizations. Closed symbols are projections onto the horizontal plane and open symbols are projections onto the vertical plane in in situ coordinates. Demagnetization temperatures in ${ }^{\circ} \mathrm{C}$.

6. The FO of Epigondolella triangularis ( $=$ E. abneptis subspecies B; Orchard, 1991a) is considered Early Norian in North America (Orchard, 1991b) (Fig. 3e).

In summary, we refer conodont events (1) and (2) to the Late Carnian, events (3), (4) and (5) to a generic Late Carnian-Early Norian or Carnian/Norian boundary, and, finally, event (6) to the Early Norian. According to this interpretation, the Pizzo Mondello section spans the
Late Carnian (middle Tuvalian or Tuvalian 2)-Early Norian (Lacian) time interval. The Carnian/Norian (Tuvalian/Lacian) boundary, generally marked by the $M$. primitius range, should fall in an interval between the LO of $P$. nodosa, $P$. polygnathiformisand $P$. carpathica at meter level 66.5 (sample Pm 18), and the FO of $E$. triangularis ( $=$ E. abneptis subspecies B; Orchard, 1991a) at meter level 105.5 (sample Pm 31). Any further subdivision is hampered by the incongruent conodont 




a)

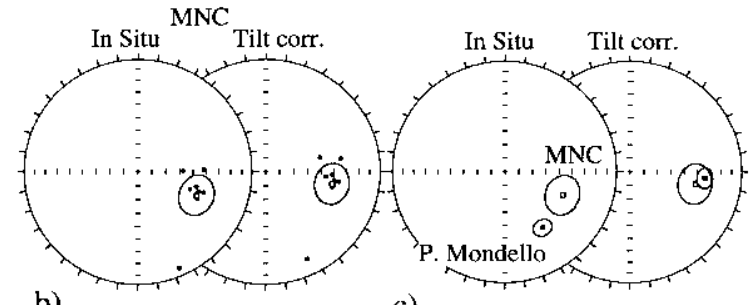

b)

c)

Fig. 6. Equal-area projections before (in situ) and after bedding tilt correction of (a) the characteristic component directions from Pizzo Mondello, (b) the characteristic component directions from site MNC bearing nearly flat-lying beds that was sampled in order to perform a fold test, and (c) the Pizzo Mondello and site MNC mean directions that clearly show evidence of clustering after correction for bedding tilt.

literature. Undisputed specimens of N. navicula (Huckriede), as well as key ammonoids, whose presence would help to locate the position of the boundary more precisiely, were not found at Pizzo Mondello.

\section{Paleomagnetism}

Paleomagnetic samples from Pizzo Mondello were drilled and oriented in the field at an average sampling interval of $1.5 \mathrm{~m}$ giving a total of 119 standard $11.4 \mathrm{cc}$ specimens for analysis. We also sampled at a site (MNC) located on the eastern bank of the 'Torrente Acque Bianche' creek (Fig. 1) which has a different bedding attitude with the aim of performing a fold test to constrain the age of the magnetization. All samples were thermally demagnetized and analyzed at the paleomagnetic laboratories of Lamont-Doherty and ETH Zürich.

The intensity of the natural remanent magnetization (NRM) at Pizzo Mondello is typically less than $0.05 \mathrm{~mA} / \mathrm{m}$. The magnetic susceptibility is generally in the diamagnetic range. The thermal unblocking characteristics of orthogonal-axes isothermal remanent magnetization (IRM) (Lowrie, 1990) show that the main carrier of the remanence is a low coercivity phase with a $570^{\circ} \mathrm{C}$ maximum unblocking temperature interpreted as magnetite (Fig. 4). A change in slope of the curves between 200 and $400^{\circ} \mathrm{C}$ (Fig. 4, sample mna 19.40) suggests either a minor amount of another ferromagnetic mineral, possibly a sulfide phase, or the presence of a coarser grain-size fraction; there is no indication of hematite.

Stepwise thermal demagnetization was applied to recover the natural magnetic remanence (NRM) whose direction was calculated by means of standard least-square analysis (Kirschvink, 1980) on Zijderveld demagnetization diagrams (Zijderveld, 1967). A soft component consistent with acquisition along the present-day field direction is removed in the $0-300^{\circ} \mathrm{C}$ temperature range in the majority of the specimens. In the temperature range between about $300^{\circ} \mathrm{C}$ and a maximum of $550^{\circ} \mathrm{C}$, a large majority $(86 \%)$ of the specimens showed the presence of a characteristic component oriented either southeastand-down or northwest-and-up interpreted as normal and reverse polarity magnetizations, respectively (Fig. 5). Subordinate north-northeasterly transitional

Table 1

Paleomagnetic directions from Pizzo Mondello section and site MNC. $N_{1}$ is the number of standard 11.44 cc specimens cut from core samples; $N_{2}$ is the number of the paleomagnetic directions used to calculate the mean. Dec., Inc.: declination and inclination; $k$ : precision parameter; $\alpha_{95}$ : radius of cone of $95 \%$ confidence about the mean directione. The paleomagnetic pole calculated from the Pizzo Mondello overall mean direction in tilt corrected coordinates is: Latitude $6.7^{\circ} \mathrm{N}$, longitude $85.7^{\circ} \mathrm{E}, \mathrm{dp} / \mathrm{dm}=4.6^{\circ} / 8.2^{\circ}$, paleolatitude $18^{\circ} \mathrm{N}$

\begin{tabular}{|c|c|c|c|c|c|c|c|c|c|}
\hline Site & $\mathrm{N} 1 / \mathrm{N} 2$ & $\begin{array}{l}\text { In situ } \\
\text { Dec. }\left(^{\circ}\right)\end{array}$ & Inc. $\left({ }^{\circ}\right)$ & $k$ & $\alpha_{95}\left({ }^{\circ}\right)$ & $\begin{array}{l}\text { Tilt corrected } \\
\text { Dec. }\left({ }^{\circ}\right)\end{array}$ & Inc. $\left({ }^{\circ}\right)$ & $k$ & $\alpha_{95}\left({ }^{\circ}\right)$ \\
\hline Pizzo Mondello & $119 / 102$ & 146.7 & 39.4 & 5.0 & 07.1 & 095.6 & 33.3 & 5.0 & 07.2 \\
\hline MNC & 009/009 & 112.1 & 43.6 & 15.5 & 13.5 & 100.6 & 40.5 & 15.5 & 13.5 \\
\hline
\end{tabular}




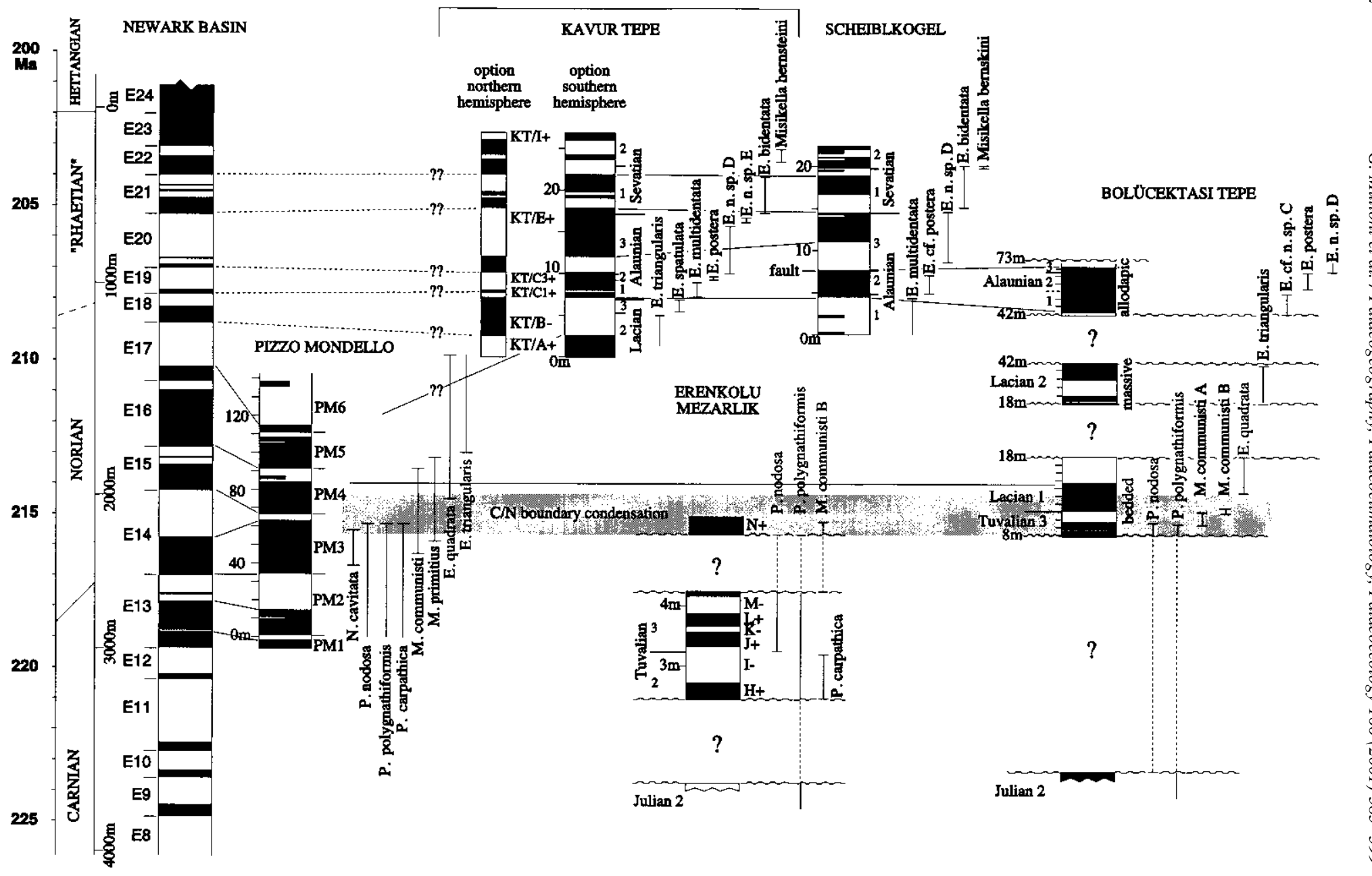

Fig. 7. Magnetostratigraphic and biostratigraphic data from Pizzo Mondello are compared with the reference sequence of polarity reversals from the Newark basin (Kent et al., 1995), and with the Tethyan Kavur Tepe, Scheiblkogel, Erenkolu Mezarlik and Bolücektasi Tepe sections of Late Triassic age (Gallet et al. 1992, 1993, 1994, 1996). Wavy lines represent discontinuities at Erenkolu Mezarlik and Bolücektasi Tepe. According to the original nomenclature given by the authors at Erenkolu Mezarlik and Bolücektasi Tepe, Paragondolella nodosa of this study is Metapolygnathus nodosus, $P$. carpathica is $M$. carpathicus, $P$. polygnathiformis is $M$. polygnathiformis and Epigondolella quadrata is Epigondolella abneptis subspec. A. Scales are in meters. See text for discussion. Note the dramatically different meter scales on the Tethyan and Newark sections. 
component directions, distributed preferentially on a great circle band between the mean normal and reversed magnetizations, also occur and are located sometimes at polarity transitions or may reflect the presence of unresolved contamination of the characteristic magnetizations by the present-day field component.

After correction for bedding tilt, the mean normal and reversed characteristic component directions turn easterly and westerly, respectively (Fig. 6a). They depart from antipodality by $40.7^{\circ}$ essentially because of the large number of transitional directions over the total, 102 characteristic directions isolated. We minimize the biasing effect due to contamination by inverting to common polarity the normal and reversed directions in order to calculate a tilt corrected average value of Dec. $95.6^{\circ}$, Inc. $33.3^{\circ}\left(\alpha_{95}=7.2^{\circ}, k=5\right.$, $N=102$ ) (Table 1) which indicates a paleolatitude of about $18^{\circ} \mathrm{N}$ for the Pizzo Mondello region at around the Carnian/Norian boundary interval. The characteristic direction from site MNC (Fig. 6b) yielded an overall mean direction which lies close to the Pizzo Mondello overall mean direction after correction for bedding tilt (Fig. 6d), thus suggesting a pre-folding age for the acquisition of the magnetic remanence.

\section{Magnetostratigraphy}

A virtual geomagnetic pole (VGP) was calculated for each characteristic component stable endpoint direction after correction for bedding tilt. The latitude of the specimen VGP with respect to the overall mean north paleomagnetic pole was used to delineate the magnetic polarity stratigraphy (Lowrie and Alvarez, 1977; Kent et al., 1995). VGP relative latitudes approaching $+90^{\circ}$ and $-90^{\circ}$ are interpreted as recording normal and reversed polarity respectively. For polarity magnetozone identification, we adapt the nomenclature used by Kent et al. (1995) wherein integers are assigned in ascending numerical order from the base of the section to polarity intervals as defined by successive pairs of predominantly normal and predominantly reversed magnetozones. Each ordinal number is prefixed by the acronym for the source of the magnetostratigraphy (i.e. 'PM' for Pizzo Mondello), and has a suffix for the dominant polarity (' $n$ ' is normal, ' $r$ ' is reversed) of each constituent magnetozone. Polarity intervals that may occur within a magnetozone are referred to as submagnetozones and can be labelled in an analogous manner, by assigning to successive pairs of submagnetozones subordinal integers (ascending upsection) which are then appended after a decimal point to the higherorder magnetozone designation and given a suffix indicating dominant polarity. The latitude of the VGPs defines at Pizzo Mondello a sequence of reversals from magnetozone PM1 to PM6. Each magnetozone is subdivided into a lower predominantly normal and an upper predominantly reversed magnetozone, in which some submagnetozones are also embedded (Fig. 2e,f). The Carnian/Norian bounday occurs between the upper part of magnetozone PM3 and the lower part of magnetozone PM5 (Fig. 2).

\section{Magnetostratigraphic correlations}

\subsection{Correlation of Pizzo Mondello with the Newark magnetic polarity sequence}

We regard the Newark magnetic polarity sequence (Kent et al., 1995) as the reference geomagnetic polarity time scale (GPTS) for the Late Triassic (Kent and Olsen, 1999) (Fig. 7). The Newark continental rift basin of eastern North America was studied at 7 partially overlapping drill sites which provided in nearly 5000 meters of composite section a detailed and virtually complete $30 \mathrm{~m}$.y. history of the Late Triassic to earliest Jurassic geomagnetic field (Kent et al., 1995). The upper part of the Newark sequence contains palynological evidence for the Triassic/Jurassic boundary which is located a few meters below the Orange Mt. basalt with associated igneous rocks radiometrically dated at $\sim 202 \mathrm{Ma}$ (Kent et al., 1995 and references therein). A $\sim 200 \mathrm{Ma}$ age for the Triassic/ Jurassic boundary was also found in ammonite-bearing marine strata from the North American Cordillera (Palfy et al., 1998). The Carnian/Norian boundary, based again on pollen biostratigraphy, should fall in an approximately $300 \mathrm{~m}$-thick interval located at the base of the Passaic Formation within magnetozone E13. Milankovitch cycle stratigraphy provides a very precise relative time scale for the Newark magnetic polarity sequence. By anchoring Milankovitch chronology to the Triassic/Jurassic boundary and associated 


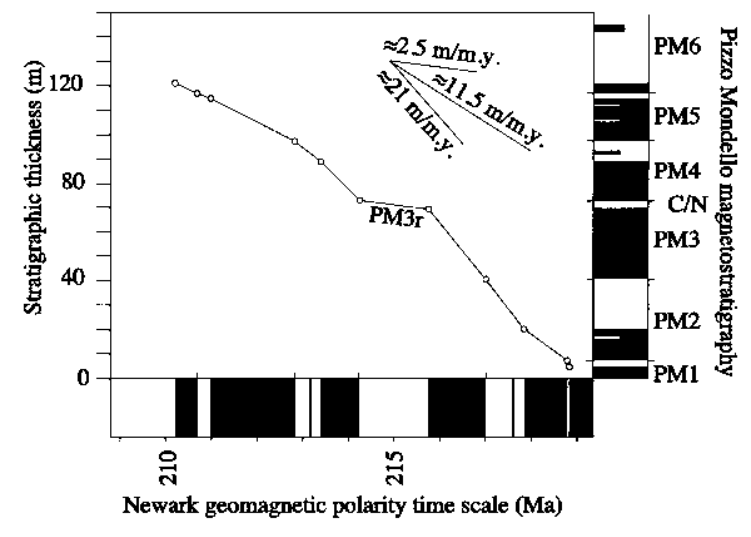

Fig. 8. Sediment thickness versus age of polarity intervals according to cyclostratigraphically calibrated Newark polarity time scale (Kent et al., 1995) for Pizzo Mondello section and for the correlative part of Newark basin section. Sloping lines are average sediment accumulation rate.

radiometric dates, Kent and Olsen (1999) constructed the first reliable GPTS for the continental Late Triassic. The time interval between the palynological Triassic/ Jurassic and Carnian/Norian boundaries based on Milankovitch cyclicity $(\sim 16$ m.y.) is similar to that estimated in most marine-based recent geologic time scales (see Kent and Olsen, 2000 for discussion).

We assign to the Mondello sequence of 12 polarity intervals (11 reversals) a nominal duration of 6 m.y. derived from Newark reversal frequency estimate of $1.8 \mathrm{rev} / \mathrm{m} . \mathrm{y}$. We then slide by one polarity reversal on the Newark reference the Mondello polarity sequence and calculate the error between the observed positions of supposedly coeval reversals and those predicted by linear curve fitting. We repeat the exercise varying the reversal frequency estimates (i.e., assuming $1,1.5$ and 2 rev/m.y.), and, by taking into account also polarity state, find highest correlation indexes with the central part of the Newark sequence between about E13 to E17 (Fig. 7). This being the case, the position of the Carnian/Norian boundary, as inferred from conodonts at Pizzo Mondello, falls somewhere between magnetozone E14r and E16n in the cyclostratigraphically dated Newark polarity succession, i.e. at least one magnetozone above the boundary based on pollen biostratigraphy at Newark. This correlation implies that the 146.5 m-thick Pizzo Mondello section encompassess about 10 m.y. of deposition at average sedimentation rates between 11.5 and $21 \mathrm{~m} / \mathrm{m}$.y., with a lower limit of $2.5 \mathrm{~m} / \mathrm{m}$.y. within PM3r within the Carnian/Norian boundary interval (Fig. 8). Biostratigraphic evidence in support of a reduction in sedimentation rate within the boundary interval are discussed below. Finally, assuming that the calcilutite/marl alternation which characterizes lithology interval (2) is cyclical and governed by precessional forcing (a hypothesis which will be fully explored in a companion paper in preparation), the Pizzo Mondello section should correspond to a total duration of 10 to 12 million years, in substantial agreement with the proposed correlation with the Newark reference sequence of reversals.

\subsection{Correlation of Pizzo Mondello with Tethyan sections from the literature}

We compare magnetostratigraphic data from Pizzo Mondello with data from the Carnian-Norian Bolücektasi Tepe section of Gallet et al. (1992) and the 5 m-thick Carnian-Early Norian Erenkolu Mezarlik section of Gallet et al. (1994). We focus our analysis on the $10 \mathrm{~m}$-thick Late Carnian-Early Norian bedded limestone member of the Bolücektasi Tepe section. This member is bounded at the base by a faulted change in lithology to a Ladinian-Carnian nodular member, and at the top by an abrupt change in lithology to an overlying extensively faulted Norian massive member. We also review data from the Norian Kavur Tepe and Scheiblkogel sections of Gallet et al. (1993).

Pizzo Mondello, Bolücektasi Tepe, Erenkolu Mezarlik, Kavur Tepe and Scheiblkogel all come from the marine Tethyan realm. However, it is very difficult to make correlations between these sections because of strong apparent differences in sedimentation rate. We expect that the highly condensed Kavur Tepe, Scheiblkogel, Bolücektasi Tepe (bedded member) and Erenkolu Mezarlik sections are also more likely to contain significant discontinuities compared to the expanded Pizzo Mondello section.

With these caveats in mind, we attempt correlation of Pizzo Mondello from the upper part of magnetozone PM3 to PM4 with the bedded member of the Bolücektasi Tepe section, and from magnetozones PM1 to PM2 with the Tuvalian part of the Erenkolu Mezarlik section somewhere between magnetozones $\mathrm{H}+$ and $\mathrm{M}-$ (Fig. 7). The 
Carnian/Norian boundary was placed at Bolücektasi Tepe and Erenkolu Mezarlik at the FO of Metapolygnathus communisti B by Gallet et al. (1992). However, as stated above, $M$. communisti $\mathrm{B}$ is here considered a doubtful subspecies which appears to be similar to Paragondolella nodosa (Orchard, pers. comm.). The magnetostratigraphic correlation that we propose brings in close concordance the LO of $P$. nodosal $? M$. communisti $\mathrm{B}$ and $P$. polygnathiformis, which are considered proxy events for the end of the Carnian stage. The correlation of Pizzo Mondello and Bolücektasi Tepe with the Newark reference seems to support a reduction in sedimentation rate in the Tethys within the Carnian/Norian boundary interval. This is also inferred from the LO of Paragondolellas and $N$. cavitata, and possibly also the FO of Epigondolella quadrataand the restricted range of Metapolygnathus communisti (dark shaded area in Fig. 7). Other discontinuities of probably local significance were found in the more condensed and discontinuous limestone facies of the Bolücektasi Tepe and Erenkolu Mezarlik sections as testified by the occurrence of concatenated (i.e. consecutive and non-overlapping) total-range zones, lack of biostratigraphic concurrent range zones and abrupt lithological variations.

The Kavur Tepe magneto-biostratigraphy was correlated with magneto-biostratigraphic data from the Scheiblkogel section by Gallet et al. (1996). The Kavur Tepe magnetozones were in turn tentatively correlated with magnetozones E14 to E19 of the Newark polarity sequence of reversals by Kent et al. (1995). These correlations would imply that Kavur Tepe and Scheiblkogel largely correspond to Pizzo Mondello magneto-biostratigraphy. However, while Kavur Tepe and Scheiblkogel (as well as the Alaunian part of the Bolücektasi Tepe section) contain similar sequences of Epigondolellas total-range zones of Norian age, they are largely younger than the Pizzo Mondello conodont fauna (Fig. 7). A better correlation is that of magnetozone KT/B-at Kavur Tepe with magnetozone PM6r at Pizzo Mondello, in turn corresponding to E17r in the Newark sequence. This would bring the LO of Epigondolella triangularis from Kavur Tepe to lie somewhere above the last finding of E. triangularis at Pizzo Mondello, and would give the Epigondolella lineage from Kavur Tepe and Scheiblkogel (and Bolücektasi Tepe) the generically younger age with respect to Pizzo Mondello which the conodont biostratigraphy demands. If magnetozone KT/B- at Kavur Tepe were correlated to magnetozone E14r in the Newark sequence (corresponding to PM3r at Pizzo Mondello), as originally proposed by Kent et al. (1995), several biostratigraphic incongruencies would be introduced, like for example that the LO of E. triangularis at Kavur Tepe would incongruently fall below the FO of E. triangularis at Pizzo Mondello.

\subsection{Discussion of correlation of Pizzo Mondello with other Late Triassic sections}

We propose, on the basis of general biostratigraphic age data, that the Norian Kavur Tepe and Scheiblkogel sections are largely younger than Pizzo Mondello, i.e. extend from magnetozone PM6r upwards, and, therefore, match younger portions of the Newark sequence, i.e. from E17r upwards, than those originally proposed by Kent et al. (1995). We explore correlations of Kavur Tepe (and Scheiblkogel) with the Newark sequence from above E17r by studying the relative position of polarity reversals assuming different sedimentation rate at Kavur Tepe beween 2.5 and $5 \mathrm{~m} / \mathrm{m}$.y. Following the method described above for the correlation between Pizzo Mondello and the Newark sequence, highest matching within sampling resolution was encountered by correlating Kavur Tepe reversals with an average sedimentation rate of $3 \mathrm{~m} / \mathrm{m}$.y. with Newark reversals straddling the E17r to E22r magnetozone interval. Introducing polarity status, however, makes such correlation visually very elusive because the E17r to E22r sequence is predominantly reversed $(68 \%)$ whereas Kavur Tepe is predominantly of normal polarity $(57 \%)$. That is to say, a satisfactory visual matching would be reached by inverting polarity, i.e. hemisphere of origin, at Kavur Tepe.

According to Gallet et al. (1993), the Kavur Tepe section from Antalya in southwestern Turkey was deposited at around $17^{\circ} \mathrm{S}$ off the coast of India in the southern hemisphere. It was tectonically displaced in post-Norian time by a minimum of $2500 \mathrm{~km}$ (latitudinal separation), but probably more then $4000 \mathrm{~km}$ if further paleogeography (i.e. longitude) is taken into account, with respect to the nearby Bolücektasi Tepe section from Antalya (Gallet et al., 1992), which was deposited at around $5-10^{\circ} \mathrm{N}$ off the northern tip of 


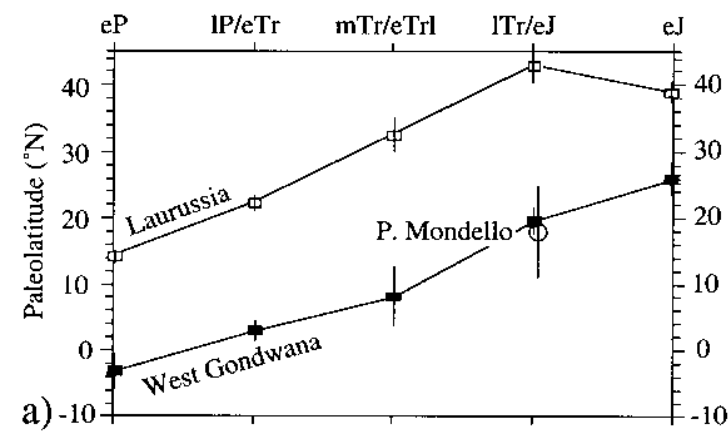

b)



Fig. 9. (a) Paleolatitude expected at Pizzo Mondello as calculated from West Gondwana and Laurussia apparent polar wander paths (Muttoni et al., 1996); eP is Early Permian, 1P/eTr is Late Permian/ Early Triassic, $\mathrm{mTr} / \mathrm{eTrl}$ is Middle Triassic/early Late Triassic, $1 \mathrm{Tr} /$ eJ is Late Triassic/Early Jurassic, eJ is Early Jurassic. The Late Triassic paleolatitude of about $18^{\circ} \mathrm{N}$ calculated from the Pizzo Mondello paleomagnetic mean direction is consistent with a West Gondwana affinity of the Pizzo Mondello area in the western Tethys during this period of time. (b) Pangea configuration in the Late Triassic/Early Jurassic (Muttoni et al., 1996) with location of the study area.

Arabia in the northern hemisphere. This interpretation rests mainly on the basis of correlation of Kavur Tepe with Scheiblkogel from Austria which was assumed to have been deposited in the northern hemisphere. The magnetostratigraphic correlation, and therefore the polarity interpretation, was largely based on conodont biostratigraphy (Gallet et al., 1996). Biostratigraphic zones, which were considered isochronous and therefore used as first order means of correlation, generally match the corresponding magnetostratigraphy at both sections, provided Kavur Tepe came from the southern hemisphere. Closer inspection of the Kavur Tepe and Scheiblkogel correlation reveals, however, that biostratigraphic incongruencies are not completely resolved with the adoption of a southern hemisphere origin for the Kavur Tepe section. In fact, $E$. multidentata at Kavur Tepe covers a mainly normal polarity interval straddling magnetozones $\mathrm{KT} / \mathrm{C} 1+$ to $\mathrm{KT} / \mathrm{C} 3+$, whereas the same species is confined within the basal reversed polarity interval at Scheiblkogel (Fig. 7). This inconsistency might suggest that conodont zones are not strictly isochronous and cannot be used for precise correlation. Alternatively, some of the biostratigraphic inconsistencies can be alleviated by recognition of disconformities and by inverting polarity at Kavur Tepe. Obviously this solution implies significant vertical axis rotation of the Kavur Tepe. However, as discussed by the original authors (Gallet et al., 1993), the Kavur Tepe forms a small klippe within a tectonically very complex region and as such large scale rotation of the unit is possible.

With regard to the possibility of unrecognized disconformities, we notice that both Kavur Tepe and Scheiblkogel sections are biostratigraphically characterized by a sequence of concatenated conodont totalrange zones in which the last occurrence of a species is followed immediately by the first occurrence of the successive species with no overlap. The fossil record when complete shows instead successions and overlap of taxa through time, manifesting the transition from one form to another and the general coexistence of taxa. Overlap between species (or the occurrence of transitional forms) is therefore to be expected in more complete sections, as appears to be the case in the expanded Pizzo Mondello section. But the fossil record is often discontinuous in condensed sections, where the transition from one species to another is usually abrupt with hardly any overlap between ranges of age-diagnostic taxa because many intervals are missing due to lack of deposition or erosion in discontinuities. Therefore, a series of concatenated total-range zones is likely to be an artifact introduced by very low sedimentation rates (i.e. about $3 \mathrm{~m} / \mathrm{m}$.y. at Kavur Tepe) and strongly points to the presence of discontinuities that will also affect magnetic polarity correlations. We note that significant discontinuities and changes in sedimentation rate have already been identified in the Bolücektasi Tepe and Erenkolu Mezarlik sections (Fig. 7). Given the above, the original biostratigraphic justification for the southern hemisphere origin of the Kavur Tepe magnetic polarity sequence and consequently the concept of the fartravelled Antalya nappes (Gallet et al., 1996) is not secure and demands further investigation. 


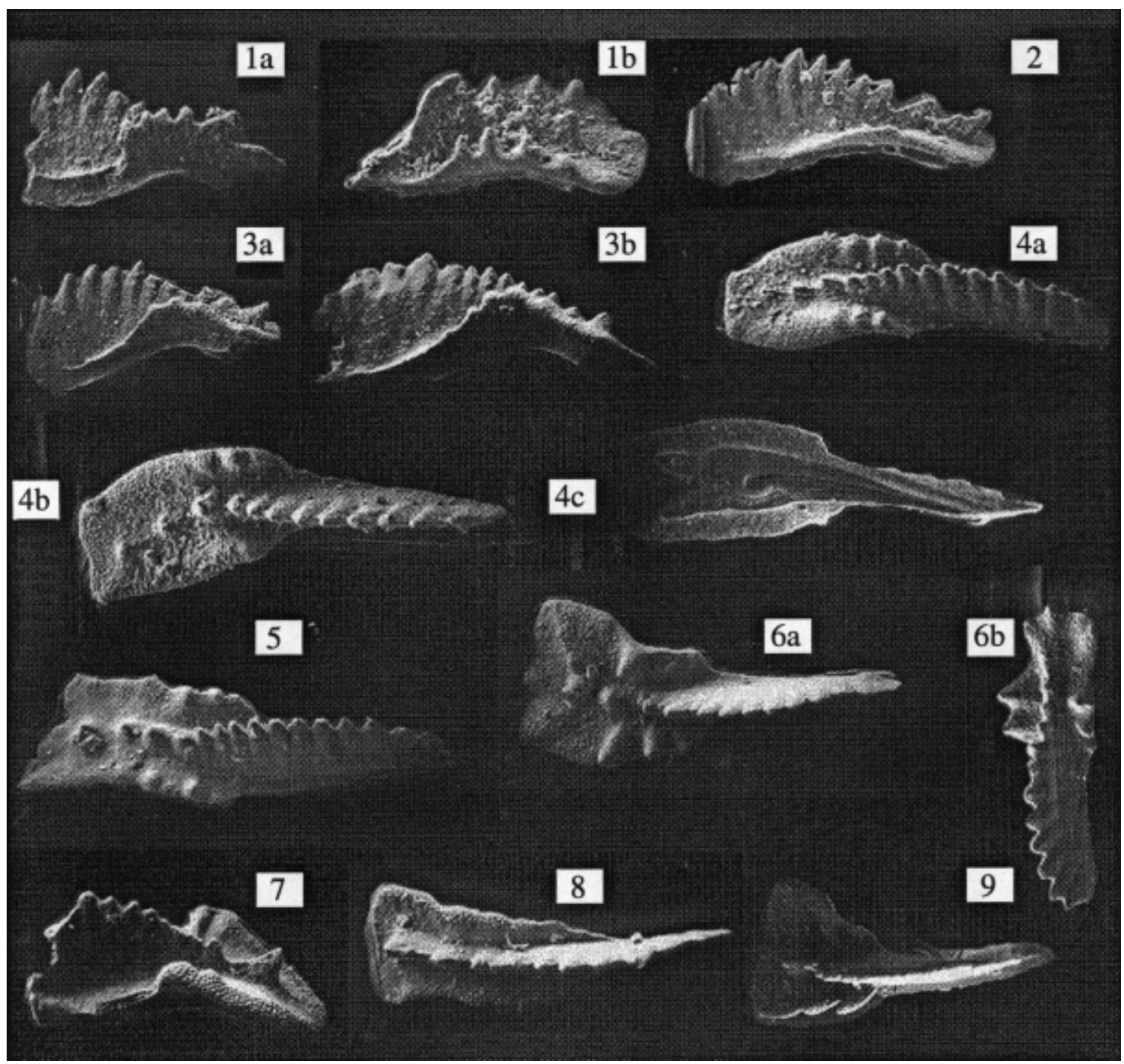

Fig. 10. Conodont species $(\times 100)$ from the Cherty Limestone Formation of the Pizzo Mondello section. Underlined are age-diagnostic species reported in Fig. 2. 1a-b. Paragondolella nodosa (Hayashi), sample PM1, (a) lateral view, (b) oblique lateral view. 2. Paragondolella polygnathiformis (Budurov and Stefanov) transition to Paragondolella nodosa (Hayashi), sample PM1, lateral view. $\underline{3 \mathrm{a}-\overline{\mathrm{b}}}$. Paragondolella carpathica (Mock), lateral view, (a) sample PM7, (b) sample PM10. 4a-c. Metapolygnathus communisti (Hayashi), sample PM27; (a) lateral view, (b) upper view, (c) lower view. 5. Metapolygnathus primitius (Mosher), sample PM26. 6a-b. Epigondolella quadrata Orchard, (a) sample PM33, (b) sample PM31. 7. Metapolygnathus stephanae Orchard, sample PM7, oblique-lateral view. 8. Metapolygnathus zoae Orchard, sample PM14. 9. Epigondolella spatulata (Hayashi), sample PM45.

\section{Conclusions}

The paleomagnetic mean direction at Pizzo Mondello after correction for bedding tilt is rotated by $102^{\circ}$ clockwise relative to the Late Triassic/Early Jurassic reference paleopole for West Gondwana
('Africa') (Muttoni et al., 1996), in agreement with Late Cretaceous data from the Sicani basin (Campofiorito and Filaga, Channell et al., 1990) and, in general, data from central-western Sicily (inset in Fig. 1 with arrows indicating paleomagnetic directions from Channell et al., 1990 and this study). 
However, a simple bedding tilt correction cannot unambiguously restore the horizontal components of paleomagnetic directions to their correct pre-deformation orientation in the case of polydeformational tectonics, for example, when tilting is generated by interference folding like in the case of the Pizzo Mondello thrust sheet. Hence, the kinematic interpretation of such paleomagnetic directions is not unique. Nevertheless, the paleolatitude of about $18^{\circ} \mathrm{N}$ calculated from the Pizzo Mondello paleomagnetic mean direction compares well with the Late Triassic/Early Jurassic palelatitude expected at Pizzo Mondello from the West Gondwana apparent polar wander path of Muttoni et al. (1996 and references therein) (Fig. 9a). We can therefore assume that Pizzo Mondello in the Sicani basin was located along the northern margin of Gondwana in the western Tethys during Late Triassic/ Early Jurassic times (Fig. 9b, after Muttoni et al., 1996), and that the Apennine tectonics triggered clockwise rotations with negligible latitudinal displacement of the study area during the Neogene.

\section{Acknowledgements}

This research was partially funded by the Consiglio Nazionale delle Ricerche (grants 1995-1998 "Stratigraphic correlations between Tethys and Peritethys") and the U.S. National Science Foundation grant (EAR94-17594). Printing expenses were partly covered by the Progetto cofinanziato ex 40\% ' Gradienti trasversali e longitudinali lungo grandi margini continentali paleozoici e triassici: definizione e distribuzione spazio- temporale delle biofacies' (Coord. Naz. Prof M. Tongiorgi, Pisa, Italia; Resp. Loc. Prof A. Nicora, Milano, Italia).Prof Maurizio Gaetani (Milano) improved an earlier version of this manuscript. We thank the reviewers Mark Hounslow (Norwich) and Cor Langereis (Utrecht) for many constructive comments. We thank Prof K. Budurov (Sofia) and Dr. Mike Orchard (Vancouver) for stimulating discussion on Triassic conodont taxonomy and stratigraphy as well as for useful comments on the conodont biostratigraphy of the Pizzo Mondello section. We wish to thank Tony Costagliola (Palermo) for photographs and Gianni Salvo, tecnician at the Geological Museum G.G. Gemmellaro in Palermo, for collecting and preparing samples for biostratigraphy. We also thank Dr. Abbate of the Ispettorato Forestale di Bivona for logistic support. This is Lamont-Doherty Earth Observatory contribution no. 6106.

\section{References}

Bellanca, A., et al., 1993. Ritrovamento di 'Calcisfere' e nannofossili calcarei in terreni carnici della Sicilia. Paleopelagos 3, 91-96.

Bellanca, A., Di Stefano, P., Neri, R., 1995. Sedimentology and isotope geochemistry of Carnian deep-water marl/limestone deposits from the Sicani Mountains, Sicily: Environmental implications and evidence for planktonic source of lime mud. Palaeogeography, Palaeoclimatology, Palaeoecology 114, 111-129.

Budurov, K., Sudar, M., 1990. Late Triassic conodont stratigraphy. Courier Forsch.-Inst. Senckenberg 118, 203-239.

Channell, J.E.T., Oldow, J.S., Catalano, R., D’Argenio, B., 1990. Paleomagnetically determined rotations in the western Sicilian fold and thrust belt. Tectonics 9 (4), 641-660.

Di Stefano, P., 1990. The Triassic of Sicily and the Southern Apennines. Boll. Soc. Geol. It. 109, 21-37.

Di Stefano, P., Alessi, A., Gullo, M., 1996. Mesozoic and Paleogene megabreccias in southern Sicily: new data on the Triassic paleomargin of the Siculo-Tunisian Platform. Facies 34, 101-122.

Gallet, Y., Besse, J., Krystyn, L., Marcoux, J., 1996. Norian magnetostratigraphy from the Scheiblkogel section (Austria): Constraint on the origin of the Antalya Nappes (Turkey). Earth and Planetary Science Letters 140, 113-122.

Gallet, Y., Besse, J., Krystyn, L., Marcoux, J., Theveniaut, H., 1992. Magnetostratigraphy of the Late Triassic Bolücektasi Tepe section (southwestern Turkey): Implications for changes in magnetic reversal frequency. Physics of the Earth and Planetary Interiors 73, 85-108.

Gallet, Y., Besse, J., Krystyn, L., Theveniaut, H., Marcoux, J., 1993. Magnetostratigraphy of the Kavur Tepe section (southwestern Turkey): A magnetic polarity time scale for the Norian. Earth and Planetary Science Letters 117, 443-456.

Gallet, Y., Besse, J., Krystyn, L., Theveniaut, H., Marcoux, J., 1994. Magnetostratigraphy of the Mayerling section (Austria) and Erenkolu Mezarlik (Turkey) section: Improvement of the Carnian (late Triassic) magnetic polarity time scale. Earth and Planetary Science Letters 125, 173-191.

Gullo, M. 1993. Studi stratigrafici sul Permiano ed il Trias pelagico della Sicilia occidentale. PhD Thesis, University of Palermo, Palermo, 203 pp., 13 plates pp.

Gullo, M., 1996. Conodont biostratigraphy of uppermost Triassic deep-water calcilutites from Pizzo Mondello (Sicani Mountains): evidence for Rhaetian pelagites in Sicily. Paleogeography, Paleoclimatology, Paleoecology 126, 309-323.

Kent, D.V, Olsen, P.E., 1999. Astronomically tuned geomagnetic polarity time scale for the Late Triassic. Journal of Geophysical Research 104 (12), 12831-12841.

Kent, D.V., Olsen, P.E., 2000. Implications of astronomical climate cycles to the chronology of the Triassic: Zbl. Geol. Palaont. Teil 
1 (Epicontinental Triassic International Symposium), pp. 14631473.

Kent, D.V., Olsen, P.E., Witte, W.K., 1995. Late Triassic-earliest Jurassic geomagnetic polarity sequence and paleolatitudes from drill cores in the Newark rift basin, eastern North America. Journal of Geophysical Research 100, 14965-14998.

Kirschvink, J.L., 1980. The least-squares line and plane and the analysis of palaeomagnetic data. Geophysical Journal of the Royal Astronomical Society 62, 699-718.

Kozur, H., 1989. Significance of events in conodont evolution for the Permian and Triassic stratigraphy. Courier Forsch.-Inst. Seneckenberg 117, 385-408.

Krystyn, L., 1980. In: Schönlaub, H. (Ed.). Second Europens Conodont Symposium, Fieldtrip B: Triassic conodont localities of the Salzkammergutes Region. Abh. Geol. B.-A., pp. 69-98.

Lowrie, W., Alvarez, W., 1977. Late Cretaceous geomagnetic polarity sequence: detailed rock and palaeomagnetic studies of the Scaglia Rossa limestone at Gubbio, Italy. Geophysical Journal of the Royal Astronomical Society 51, 561-581.

Lowrie, W., 1990. Identification of ferromagnetic minerals in a rock by coercivity and unblocking temperature properties. Geophysical Research Letters 17, 159-162.

Muttoni, G., Kent, D.V., Channell, J.E.T., 1996. The Evolution of Pangea: Paleomagnetic constraints from the Southern Alps, Italy. Earth and Planetary Science Letters 140, 97-112.

Oldow, J.S., Channell, J.E.T., Catalano, R., D’Argenio, B., 1990. Contemporaneous thrusting and large-scale rotations in the western Sicilian fold and thrust belt. Tectonics 9, 661-661.
Orchard, M., Tozer, E.T., 1997. Triassic conodont biochronology, its calibration with the ammonoid standard, and a biostratigraphic summary for the western Canada sedimentary basin. Bull. of Canadian Petroelum Geology 45 (4), 675-692.

Orchard, M., 1983. Epigondolella populations and their phylogeny and zonation in the Upper Triassic. Fossils and Strata 15, 177-192.

Orchard, M.J., 1991a. Conodonts, time and terranes: an overview of the biostratigraphic record in the western Canadian Cordillera. In: Orchard, M.J., McCracken, A.D. (Eds.). Ordivician to Triassic Conodont Paleontology of the Canadian Cordillera. Bull. Geol. Surv. Canada, pp. 1-25.

Orchard, M.J., 1991b. Upper Triassic conodont biochronology and new index species from the Canadian Cordillera. In: Orchard, M.J., McCracken, A.D. (Eds.). Ordivician to Triassic Conodont Paleontology of the Canadian Cordillera. Bull. Geol. Surv, Canada, pp. 299-335.

Palfy, J., Smith, P.L., Mortenson, J.K., 1998. A U-Pb and 40Ar39Ar time scale for the Jurassic. 5th International Symposium on the Jurassic System, Vancouver, August 1998, 72.

Sudar, M., Budurov, K., 1979. New Conodonts from the Triassic in Yugoslavia and Bulgaria. Geologica Balcanica 9 (3), 47-52.

Vrielynck, B., 1987. Conodontes du Trias perimediterraneen. Systematique, Stratigraphie. Doc, 97. Lab. Géol, Lyon, p. 301.

Zijderveld, J.D.A., 1967. A.C. demagnetization of rocks —analysis of results. In: Collinson, D.W., Creer, K.M., Runcorn, S.K. (Eds.). Methods in Paleomagnetism. Elsevier, New York, pp. 254-286. 